\title{
'Twenty-four-and-a-half' syndrome and contralateral hemifacial spasm due to pontine carvernoma
}

\author{
Bik Ling Man, Yat Pang FU
}

Department of Medicine and Geriatrics, Tuen Mun Hospital, Hong Kong, People's Republic of China

\section{Correspondence to}

Dr Bik Ling Man,

beli_man@yahoo.com

Accepted 24 March 2014
CrossMark

To cite: Man BL, FU YP. BMJ Case Rep Published online: [please include Day Month Year] doi:10.1136/ bcr-2013-203268

\section{DESCRIPTION}

A 50-year-old man who enjoyed good health in the past was admitted for diplopia, acute hearing loss of both ears and left-sided limb clumsiness on waking up. Physical examination showed right one-and-a-half syndrome (figure 1A-I and video 1), lower motor neuron weakness of the right face

(a)

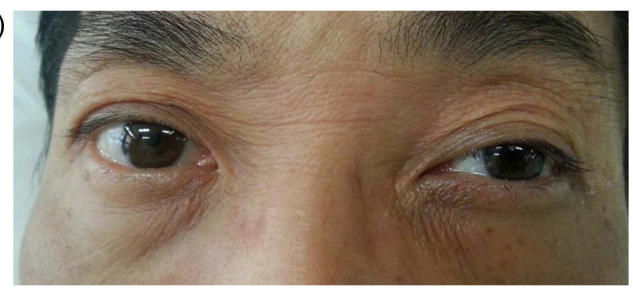

(c)

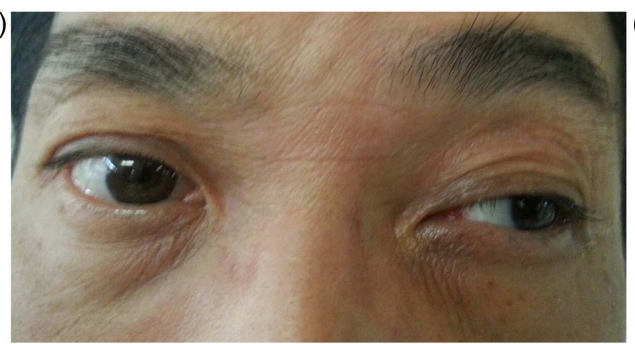

(e)

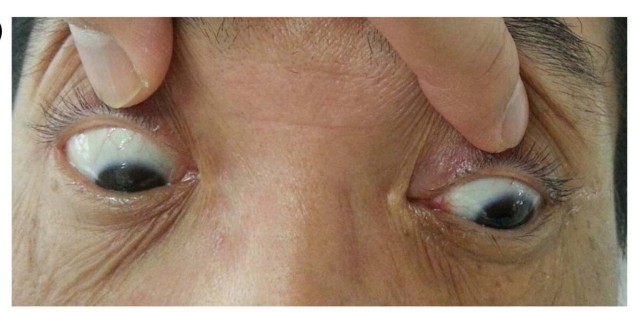

(g)

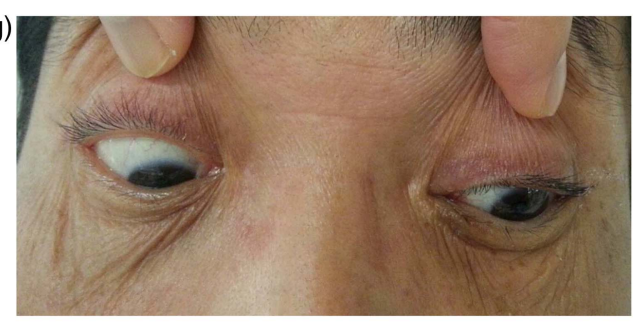

muscles (video 2), hemifacial spasm on the left side of the face (video 3), bilateral hearing loss and ataxia of left limbs (video 4). MRI of the brain revealed a right pontine carvernoma with perilesional oedema (figure $2 \mathrm{~A}, \mathrm{~B}$ ). Urgent operation for removal of pontine carvernoma was performed and his condition improved afterwards.
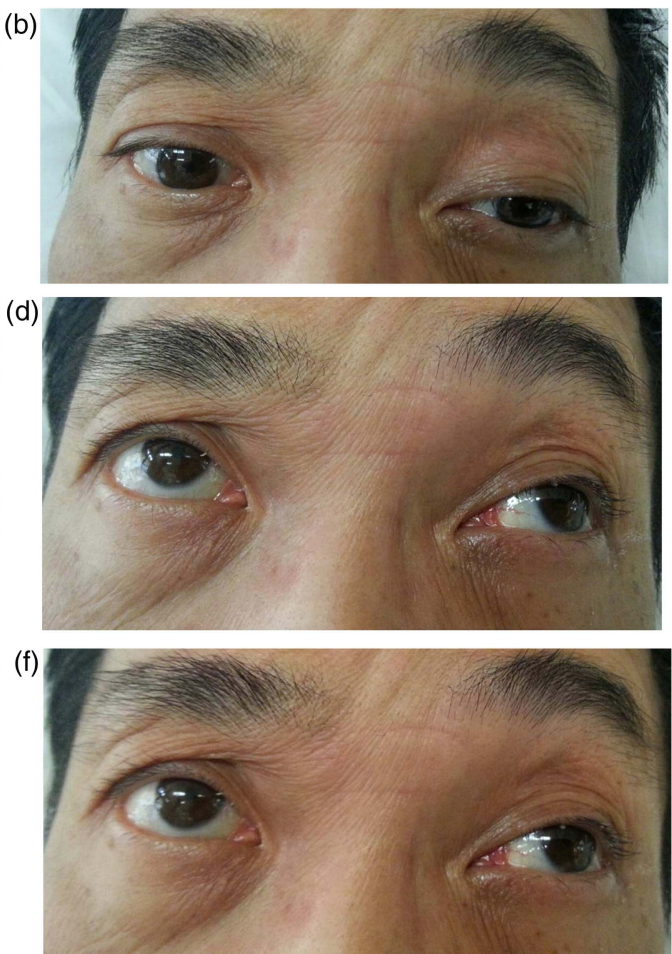

(h)

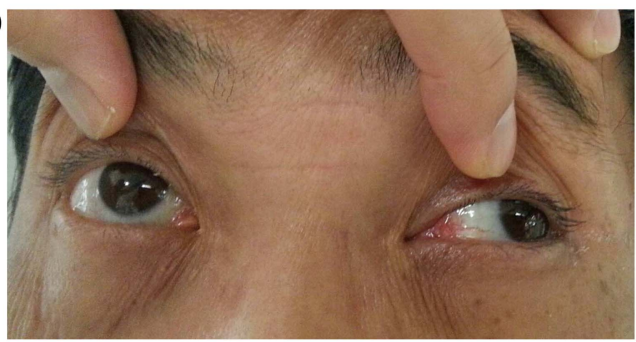

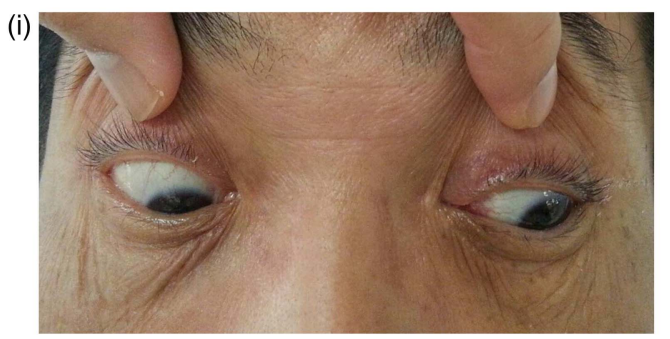

Figure 1 (A) Looking straight, (B) looking towards the right, (C) looking towards the left, (D) looking straight up, (E) looking straight down, (F) looking up and right, $(\mathrm{G})$ looking down and right, $(\mathrm{H})$ looking up and left and (I) looking down and left. 


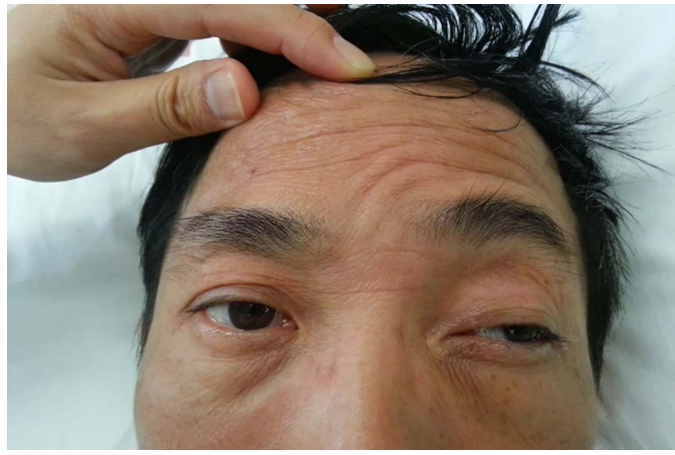

Video 1 Left hemifacial spams.

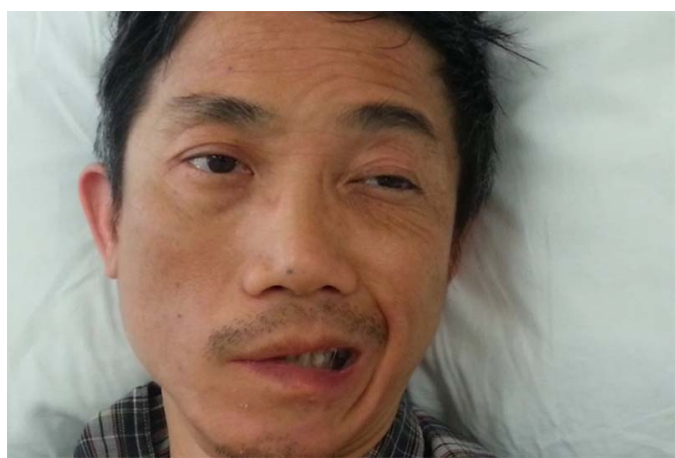

Video 2 Ataxia.

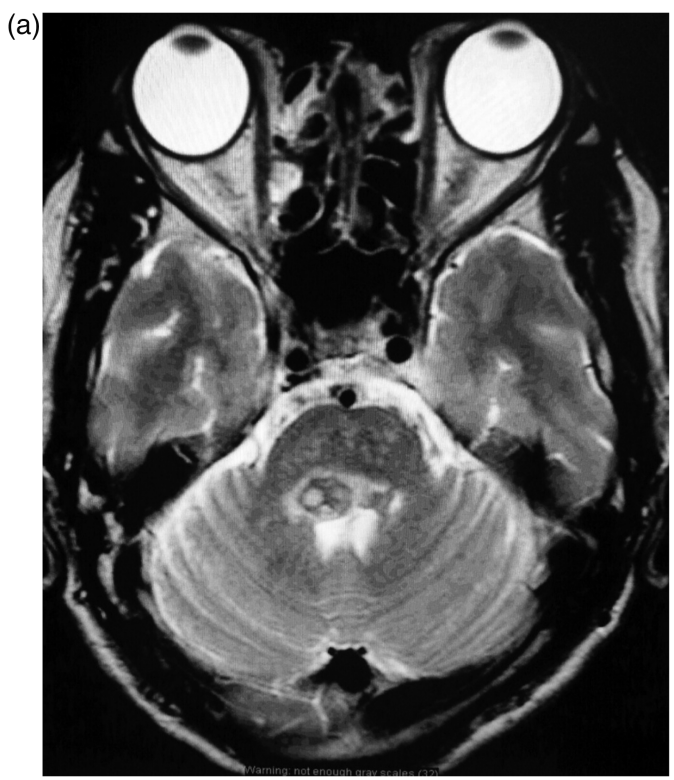

Figure 2 (A) MRI T2-weighted image showed an oval lesion with mixed signal intensity on the right side of the pons associated with perilesional oedema. (B) MRI gradient echo image showed prominent blooming artefact particularly at the rim of the lesion suggesting cavernoma with recent haemorrhage.

'Twenty-four-and-a-half' syndrome is a novel pontine neuro-ophthalmological condition characterised by 'one-anda-half' syndrome with additional ipsilateral seventh and bilateral eighth cranial nerve palsies $\left(1 \frac{1}{2}+7+8+8=24 \frac{1}{2}\right)$. This is caused by a right pontine carvernoma with perilesional oedema involving the ipsilateral abducens nucleus and the adjacent medial longitudinal fasciculus (MLF), or alternatively the
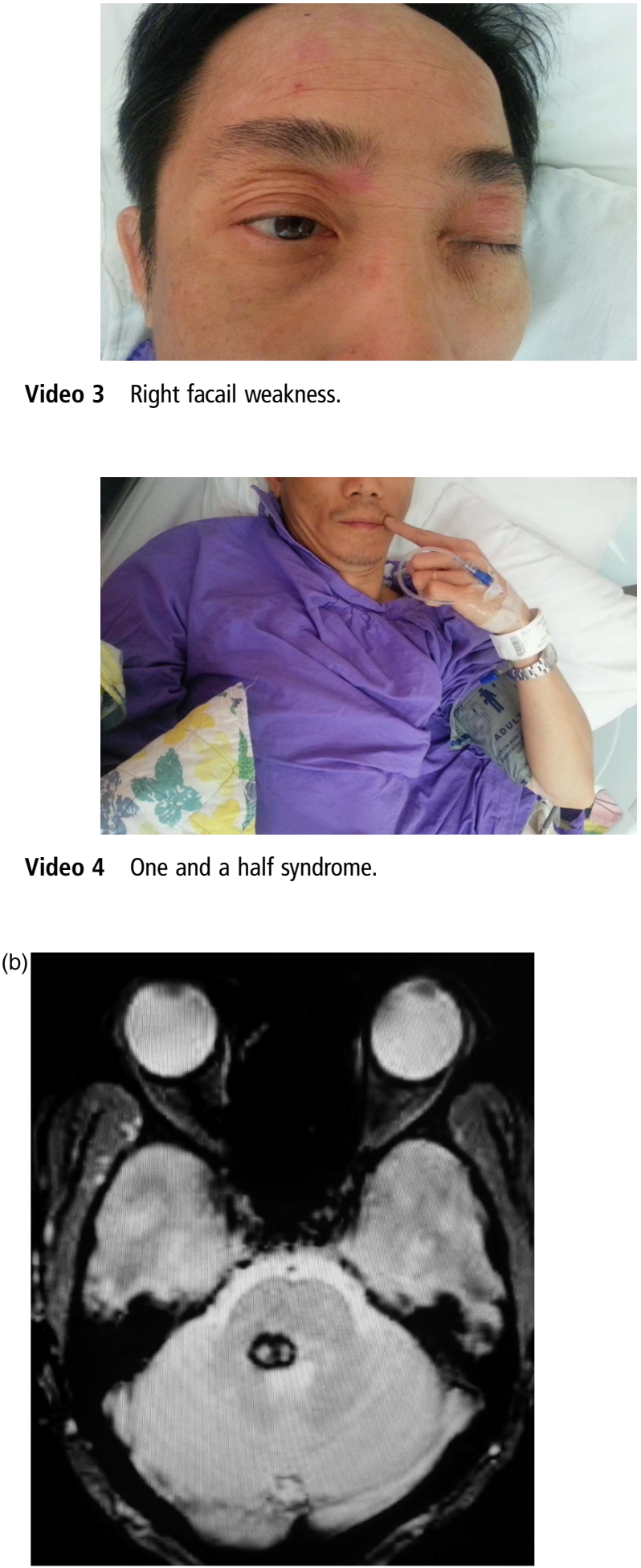

Video 3 Right facail weakness.

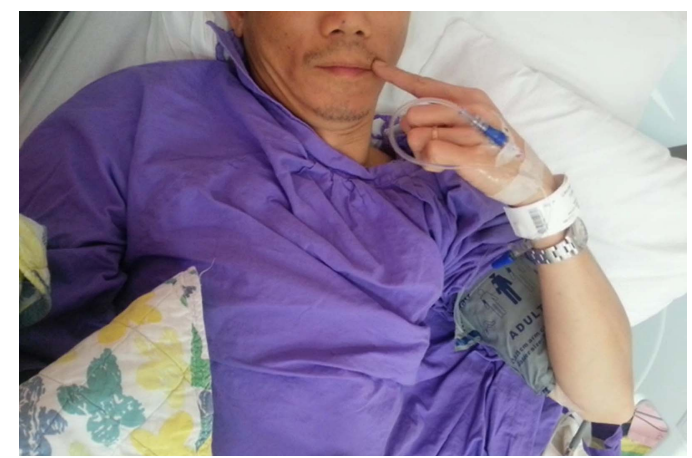

Video 4 One and a half syndrome.

involvement of the MLF plus the paramedian pontine reticular formation, along with ipsilateral facial nerve in this patient. Deafness is likely due to involvement of the cochlear nucleus complex bilaterally. ${ }^{1}$ The contralateral hemifacial spasm may be related to oedema of the contralateral dorsal pontine tegmentum causing hyperexcitability of the contralateral facial nerve motoneurons. ${ }^{2}$ 


\section{Learning points}

- 'Twenty-four-and-a-half' syndrome is a novel pontine neuro-ophthalmological condition characterised by 'one-and-a-half' syndrome with additional ipsilateral seventh and bilateral eighth cranial nerve palsies.

- It is caused by a right pontine carvernoma with perilesional oedema involving the ipsilateral abducens nucleus and the adjacent medial longitudinal fasciculus (MLF), or alternatively the involvement of the MLF plus the paramedian pontine reticular formation, along with ipsilateral facial nerve in this patient. Deafness is likely due to involvement of the cochlear nucleus complex bilaterally.

- The contralateral hemifacial spasm may be related to oedema of the contralateral dorsal pontine tegmentum causing hyperexcitability of the contralateral facial nerve motoneurons.
Competing interests None.

Patient consent Obtained.

Provenance and peer review Not commissioned; externally peer reviewed.

\section{REFERENCES}

1 Cummins G, O'Hare A, Dunne R, et al. 'Sixteen and a half': a novel pontine neuro-ophthalmological syndrome. J Neurol 2011;258:1347-8.

2 Aramideh $M$, Ongerboer de Visser BW, Holstege $G$, et al. Blepharospasm in association with a lower pontine lesion. Neurology 1996;46:476-8.

Copyright 2014 BMJ Publishing Group. All rights reserved. For permission to reuse any of this content visit http://group.bmj.com/group/rights-licensing/permissions.

BMJ Case Report Fellows may re-use this article for personal use and teaching without any further permission.

Become a Fellow of BMJ Case Reports today and you can:

- Submit as many cases as you like

- Enjoy fast sympathetic peer review and rapid publication of accepted articles

- Access all the published articles

- Re-use any of the published material for personal use and teaching without further permission

For information on Institutional Fellowships contact consortiasales@bmjgroup.com

Visit casereports.bmj.com for more articles like this and to become a Fellow 